\title{
Розробка модифікованих сітчастих полімерних ендопротезів з плівковим покриттям
}

\author{
Ю. О. Фурманов ${ }^{1}$, І. М. Савицька 1 , Г. В. Дударенко ${ }^{2}$ Н. В. Ярова ${ }^{2}$, Н. А. Федорова \\ Т. О. Хавіна ${ }^{3}$, О. А. Гейленко ${ }^{1}$, О. І. Яцина ${ }^{4}$ \\ ${ }^{1}$ Національний інститут хірургії та трансплантології імені О. О. Шалімова НАмН України, м. Київ, \\ ${ }^{2}$ Інститут хімії високомолекулярних сполук НАН України, м. Київ, \\ ${ }^{3} \mathrm{TOB} \ll$ Еспера», м. Київ, \\ ${ }^{4}$ Одеський національний медичний університет \section{with the film coating} \\ Elaboration of modified meshy polymeric endoprosthesis
}

\author{
Yu. O. Furmanov ${ }^{1}$, I. M. Savytska ${ }^{1}$, G. V. Darenko ${ }^{2}$, N. V. Yarova ${ }^{2}$, N. A. Fedorova ${ }^{3}$, \\ T. O. Khavina ${ }^{3}$, O. A. Geylenko ${ }^{1}$, O. I. Iatsyna ${ }^{4}$ \\ ${ }^{1}$ Shalimov National Institute of Surgery and Transplantology, Kyiv, \\ ${ }^{2}$ Institute of Chemistry of High-Molecular Compounds, Kyiv, \\ ${ }^{3}$ LLP «Espera», Kyiv, \\ ${ }^{4}$ Odesa National Medical University
}

\section{Реферат}

Мета. Розробка плівкового покриття для модифікації сітчастих поліпропіленових ендопротезів для підвищення біосумісності та зниження частоти операційних ускладнень у вигляді спайок, алергічних реакцій тощо.

Матеріали і методи. ТОВ «Еспера» та Інститутом хімії високомолекулярних сполук НАН України виготовлені зразки сітчастих напіврозчинних ендопротезів, потім лабораторним тваринам виконана їх внутрішньочеревна фіксація. Імплантований сітчастий матеріал разом із навколишніми тканинами досліджували через 7, 30, 60, 90,180 та 365 діб після операції.

Результати. Створені нові напіврозчинні сітчасті ендопротези з плівкою карбоксиметилцелюлози (КМЦ), яка виконує роль протиспайкового бар'єру. Нові сітчасті матеріали патентоспроможні та придатні для застосування в хірургічному лікуванні травмованих поверхонь, а також для зміцнення тканин в лікуванні гриж різної локалізації.

Висновок. Сітчастий полімерний ендопротез має виражену біосумісність, що забезпечує зниження частоти операційних ускладнень у вигляді спайок та алергічних реакцій та розширює спектр застосування таких комбінованих біопротезів.

Ключові слова: сітчасті напіврозчинні ендопротези; імплантація; протиспайковий бар'єр; плівка карбоксиметилцелюлози; біодеструкція; біосумісність.

\section{Abstract}

Objective. Elaboration of the blend coverage for modification of meshy polypropylene endoprosthesis for enhancement of biocompatibility and lowering of postoperative morbidity rate, such as the adhesions and allergic reactions occurrence etc.

Materials and methods. By LLP «Espera» and Institute of Chemistry of High-Molecular Compounds NAS of Ukraine the examples of meshy hemisoluble endoprosthesis were manufactured, afterwards their intraabdominal fixation was performed in laboratory animals. The meshy material implanted together with adjacent tissues were investigated in 7, 30, 60, 90, 180 and 365 days postoperatively.

Results. New hemisoluble meshy endoprosthesis with blend of carboxymethylcellulose, which play a role as antiadhesion barrier, were created. New meshy materials are a patent-affordable and eligible in surgical treatment of the injured surfaces and for the tissues strengthening in treatment of hernias of various localization.

Conclusion. Meshy polymeric endoprosthesis has pronounced biocompatibility, guaranteeing lowering of the operative complications rate, such as adhesions and allergic reactions, and expands spectrum of application of such combined bioprosthesis

Keywords: meshy hemisoluble endoprosthesis; implantation; antiadhesion barrier; blend of carboxymethylcellulose; diodestruction; biocompatibility.

Розвиток зрощень учеревній порожнині часто ускладнює операції, проведені з використанням сітчастих ендопротезів, та переважно починається 3 пошкодження мезотелію очеревини з подальшим ії запаленням [1 4]. Тому більшість дослідників зосереджується на пошуках засобів для зменшення проявів запалення та надання імплантованим полімерам біосумісних властивостей. Основними заходами профілактики спайкового процесу є запобігання пошкодженням мезотелію; зниження запальної реакції в зоні операції; зменшення вірогідності утворення плівки фібрину у вільній черевній порож- нині; відмежування або відокремлення пошкоджених серозних поверхонь від сітчастих імплантатів за допомогою створення захисних бар'єрів [5 - 7].

Сучасними засобами, що можуть частково вирішити проблему утворення спайок, вважаються плівки та гелі на основі колагену, ефірів целюлози, полівінілпіролідону, хітозану та інших біополімерів. Гідрофобні поверхнево-активні речовини, наприклад фосфатдикарбоксиметилцелюлоза, утворюють плівку на очеревині, тим самим перешкоджаючи адгезії поверхонь [8 - 10]. Заслуговують на увагу експериментальні дослідження 


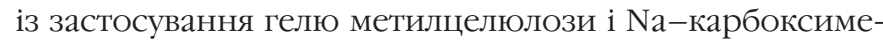
тилцелюлози для формування протиспайкового бар'єру $[11,12]$.

В експериментальних дослідженнях процесів утворення спайок КМЦ згадується з середини $80-x$ років. За період, що минув, накопичені численні дані про ефективність застосування іiі 1 - 3\% розчинів у профілактиці утворення спайок. Найбільш ефективною для клінічної профілактики утворення спайок виявилася комбінація КМЦ і гіалуронової кислоти, на їх основі створено біорозчинні мембрани [13]. Коли ці мембрани використовували з метою профілактики адгезії, вони не впливали на черевну фібринолітичну активність. Натомість фізичні властивості (бар'єрний, гідрофлотаційний ефекти) мембран у першу чергу відповідальні за профілактику адгезії $[14,15]$.

Мембрани у вигляді плівки покривають травмовані поверхні, поступово перетворюючись на гель впродовж 24 - 48 год, повністю розсмоктуються через 28 днів, не потребують додаткової фіксації, ефективні у присутності крові [13].

У результаті наукових розробок, здійснених Інститутом хімії високомолекулярних сполук НАН України, відділом експериментальної хірургії Національного інституту хірургії та трансплантології імені О. О. Шалімова НАМН України та ТОВ «Еспера», створені сітчасті поліпропіленові ендопротези з плівковим покриттям на основі КМЦ.

\section{Матеріали і методи дослідження}

Метою проведеної дослідницької роботи була розробка плівкового покриття для модифікації сітчастих поліпропіленових ендопротезів, яке забезпечувало б підвищення біосумісності та зниження частоти операційних ускладнень у вигляді спайок, алергічних реакцій тощо.

Сітчастий ендопротез (СЕП) для дослідження виготовляли з поліпропіленової великочарункової сітки розмірами 6 × 11 см. Для цього готували полімерну композицію з натрієвої солі КМЦ та гіалуронової кислоти в дистильованій воді. Натрієва сіль КМЦ у воді набухала і розчинялась протягом 3 - 5 діб. Компоненти суміші використовували в таких пропорціях: натрієва сіль КМЦ 2 - 4 мас.\%; гіалуронова кислота - 0,002-0,005 мас.\%; вода - 95,995 - 97,998 мас.\%.

Перед нанесенням суміші на поліпропіленову сітку останню опромінювали не менше 20 хв ультрафіолетовою лампою інтенсивністю $4-4,5$ мВт $/ \mathrm{cm}^{2}$ та довжиною хвилі 285 - 425 нм для надання полярності поверхні. Отриману композицію наносили на опромінену поліпропіленову сітку в такій послідовності:

на оброблену етиловим спиртом поверхню лавсанової плівки наносили шар гелю товщиною 5 мм; накладали полімерну сітку, яку покривали шаром гелю товщиною 2 - 3 мм; даний триплекс покривали лавсановою плівкою і вирівнювали поверхню; знімали лавсанову плівку і висушували композит при температурі 20 $25^{\circ} \mathrm{C}$ до повного висихання гелю.

Експерименти з дослідження властивостей нового сітчастого ендопротеза були проведені на шестимісячних білих щурах вагою 180 - 200 г з дотриманням ви- мог Закону України №1759-IV від 15 грудня 2009 р. «Про захист тварин від жорсткого поводження» та «Науковопрактичних рекомендацій по утриманню лабораторних тварин і роботі з ними» ДФЦ МОЗ України (протокол №8 від 22.06.2012). Операційні втручання здійснювали під загальним внутрішньочеревним наркозом $(0,2$ мл 5\% розчину тіопенталу натрію та 0,4 мл $1 \%$ розчину пропофолу) в стерильних умовах.

У першій серії експериментів використовували вільні плівки КМЦ без поліпропіленової основи, які підсаджували в підшкірні кишені, отримані відшаруванням медичним інструментом шкіри від нижче розташованих тканин. Вільною плівкою КМЦ площею 2 см² вкривали фасцію м'язів черевної порожнини. Також вільною плівкою КМЦ вкривали поверхню шлунку.

У другій серії експериментів використовували поліпропіленові СЕП, покриті полімерною плівкою КМЦ. Тваринам цієї серії після обробки операційного поля по білій лінії живота робили розріз довжиною 3 см, по лінії апоневрозу - розріз довжиною 1,5 см для розтину черевної порожнини. Через розріз у вільну черевну порожнину вводили та розправляли там СЕП, покритий полімерною плівкою КМЦ, який фіксували ниткою пролен № 6,0 обвивним швом до черевної стінки. Рану шкіри зашивали окремими вузловими швами.

Імплантований матеріал разом з фрагментами навколишніх тканин виймали через 30, 60, 90 та 180 діб після операції, після чого фіксували в розчині формальдегіду з об'ємною часткою 10\% 24 год, ущільнювали у парафіні за загальноприйнятою схемою. Зрізи товщиною 7 мкм забарвлювали гематоксиліном та еозином, пікрофуксином за методом ван Гізона. Препарати вивчали з застосуванням світлооптичного мікроскопа Leica ICC50 HD.

\section{Результати та іх обговорення}

У першій серії експериментів після імплантації плівки КМЦ через 7 діб спостерігались ії виражена деструкція, фрагментація і лізис, у зоні розміщення утворювався тонкий прошарок грануляційної тканини, в якій були овальні гомогенні включення, оточені капсулами з 1 - 3 рядів фібробластів (рис. 1). У внутрішніх шарах капсул на межі зі збереженими фрагментами плівки КМЦ містились активовані макрофаги з пінистою цитоплазмою. Більш товсті пучки колагенових волокон визначались по периферії зони імплантації, а тонкі починали проростати вглиб цієї зони.

Через 30 діб плівка, розділена на маленькі острівці, проростала сполучною тканиною (рис. 2). Острівці були оточені макрофагами і лімфоцитами, цитоплазма макрофагів заповнена прозорим матеріалом, очевидно фрагментами КМЦ. Екстрацелюлярні гомогенні фрагменти КМЦ були оточені тонкими капсулами з одного шару фібробластів і мережі колагенових волокон. Ознак запалення в навколишніх тканинах не було.

Через 60 діб у зоні імплантації плівки КМЦ формувався невеликий масив рясно васкуляризованої сполучної тканини. Кровоносні судини утворювали густу мережу, в якій переважали капіляри великого діаметру і вени. Тканина була помірно зріла, не щільна, без виражених ознак колагеноутворення. Фрагменти стороннього матеріалу не виявлялись. 


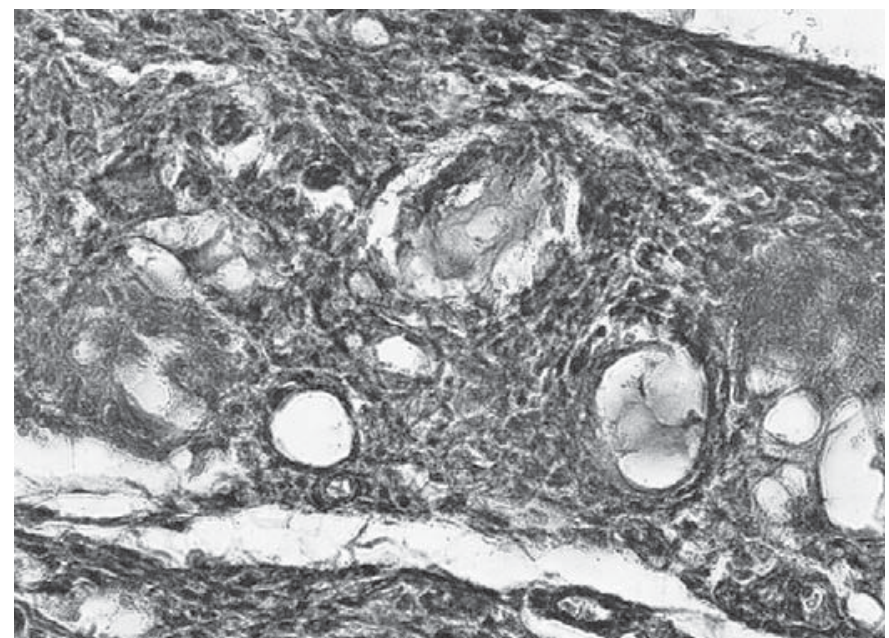

Puc. 1.

Miкpoфomo.

Фрагменти КМЦ в новоутвореній тканині через 7 діб. Забарвлення гематоксиліном та еозином. 3б. ×400.

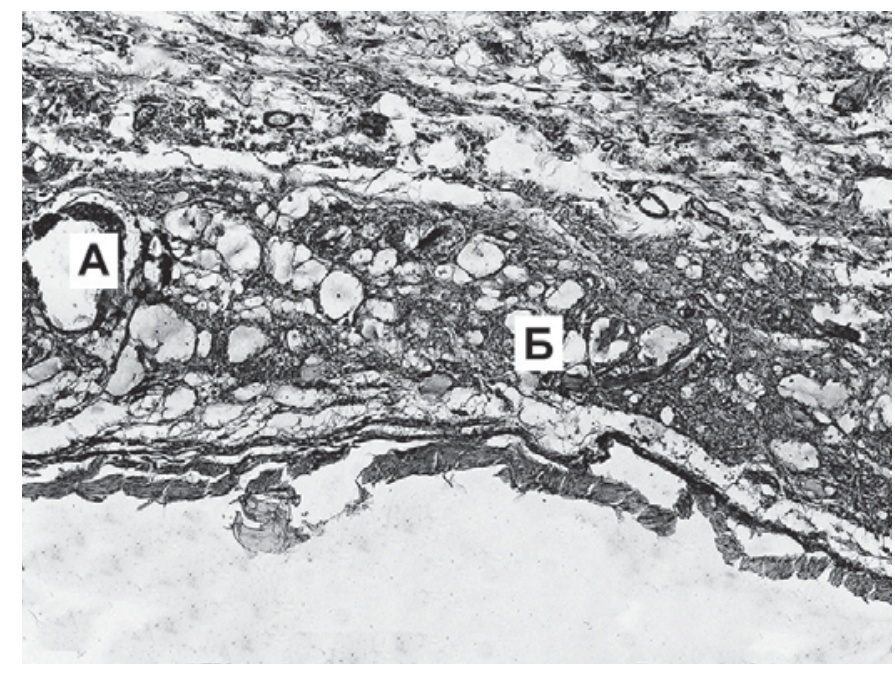

Puc.3.

Мiкрофото.

Зона імплантації сітчастого поліпропіленового протеза через 14 діб.

A - капсула навколо поліпропіленового філаменту; Б- зона розмімення фрагментів КМЦ.

Забарвлення гематоксиліном та еозином. 3б. ×100.

У терміни 90 - 180 діб місце імплантації вдавалось виявити завдяки маркерним ниткам та невеличкому надлишку зрілої сполучної тканини, що утворювалась в зоні імплантації.

Після імплантації плівки КМЦ на поверхні шлунку через 7 діб місце ііі розташування майже не виявлялось, зберігались лише маркерні нитки. Фрагментів КМЦ не виявлено, мезотелій був непошкоджений, явища запалення відсутні. Плівка зникла, напевно, розчинилась. В подальші терміни залишків плівки КМЦ також не було виявлено.

У другій серії експериментів після імплантації СЕП, покритих полімерною плівкою КМЦ, через 14 діб зона розташування повністю проростала сполучною тканиною, яка була досить пухкою в чарунках і більш щільною в ділянках переплетення поліпропіленових філаментів за рахунок формування більш товстих пучків колагено-

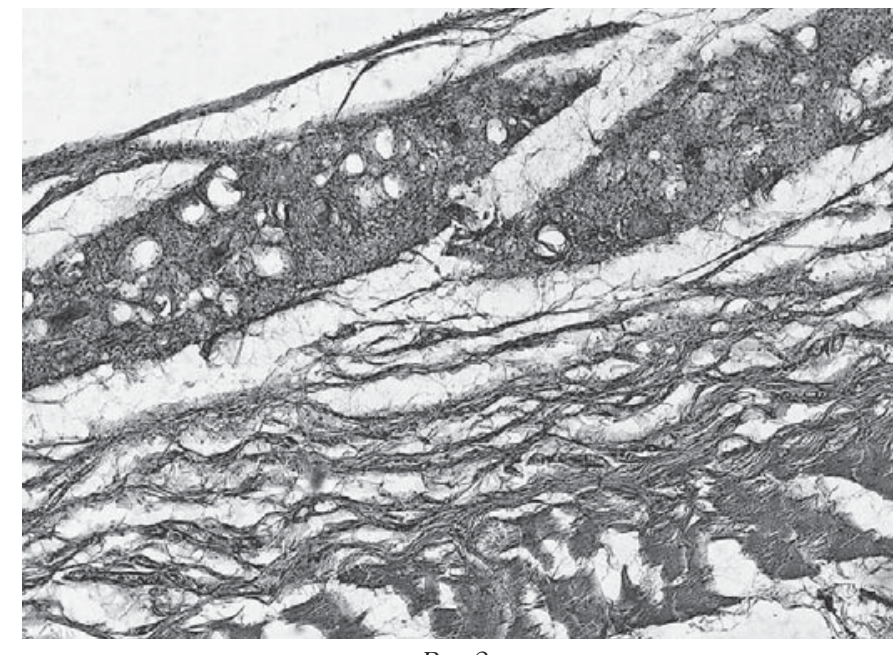

Puc.2.

Miкpoфomo.

Фрагменти КМЦ в новоутвореній тканині через 30 діб. Забарвлення гематоксиліном та еозином. Зб. ×100.

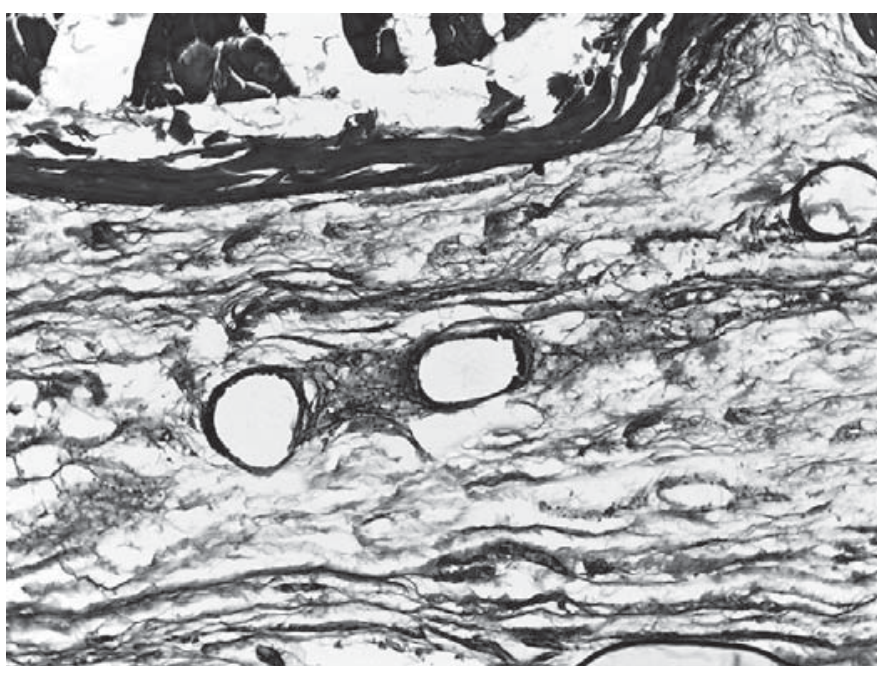

Puc. 4.

Miкрофбото.

Зона ілплантації сітчастого поліпропіленового протеза через 90 діб.

Забарвлення пікрофуксином за ван Гізоном. 3б. ×100.

вих волокон (рис. 3). В зоні імплантації гомогенні слабко базофільні фрагменти плівки КМЦ були оточені $1-2$ рядами фібробластів, до складу капсул входили також 1 - 2 макрофаги. В зоні розташування сітчастого матеріалу відзначали добре розвинену систему судин гемомікроциркуляторного русла.

На 30-ту добу відмічена деструкція значної частини плівки КМЦ на сітчастому поліпропіленовому проте3і. Спостерігались нечисленні макрофагальні гранульоми, а також невеликі фрагменти частково збереженого матеріалу, оточені тонкостінними капсулами. Навколо імплантату не формувалась загальна капсула, новоутворена тканина проростала в чарунки сітки, заміщуючи фрагменти КМЦ. Тканина у чарунках була пухка, містила значну кількість лімфоцитів і макрофагів, нечисленні гігантські клітини стороннього тіла. На деяких ділянках поблизу поліпропіленових філаментів позаклітинно ви- 
значали прозорі гранули, що не сприймали забарвлення. Фрагменти КМЦ і піниста цитоплазма макрофагів були помірно ШИК-позитивні.

Через 60 діб імплантат проріс сполучною тканиною, з боку черевної порожнини був вкритий вісцеральним листком очеревини з відновленим мезотелієм на черевній поверхні ендопротезу. Спостерігали виражену резорбцію шару КМЦ, зберігались лише поодинокі дрібні гомогенні фрагменти поблизу сполучнотканинних капсул, які оточували поліпропіленові філаменти сітчастого матеріалу. Новоутворена тканина проникала в чарунки сітчастого матеріалу, заміщаючи фрагменти КМЦ. Замість фрагментів КМЦ були помітні скупчення макрофагів 3 пінистою цитоплазмою, об'єднаних ніжною мережею колагенових волокон і нечисленними фібробластами.

Через 90 діб імплантат повністю проріс невеликою кількістю досить пухкої сполучної тканини, капсули навколо його філаментів були тонкі. На деяких ділянках визначали невеликі скупчення макрофагів з ШИК-позитивною цитоплазмою. Екстрацелюлярних фрагментів КМЦ не спостерігали (рис. 4).

Через 180 діб СЕП повністю проріс досить пухкою шаруватою сполучною тканиною, в якій на деяких ділянках спостерігали невеликі жирові часточки. На деяких ділянках відмічені великі овальні скупчення макрофагів 3 димчасто-базофільною цитоплазмою. В зоні розташування поліпропіленових філаментів тканина була васкуляризована повнокровними кровоносними судинами.

Через 365 діб в зоні розташування СЕП сформувався досить тонкий прошарок зрілої сполучної тканини, який значно потовщувався в місцях переплетення поліпропіленових ниток. У всіх чарунках сітчастого матеріалу знаходились невеликі скупчення макрофагів, що були розділені вузькими пухкими прошарками зрілої сполучної тканини.

\section{Висновки}

1. Сітчастий полімерний ендопротез має виражену біосумісність, що забезпечує зниження частоти операційних ускладнень у вигляді спайок та алергічних реакцій.

2. Виражена біосумісність комбінованих біопротезів є підставою для розширення спектру їх застосування.

\section{References}

1. Rubanchenko DO. Sovremennyie podhodyi k hirurgicheskomu lecheniyu spaechnoy bolezni bryushinyi i vnedreniyu protivospaechnyih implantatov (Modern approaches to surgical treatment of peritoneal adhesive disease and application of adhesion barriers). Vestnik RGMU. 2010; 2:212. [In Russian]

2. Nemilov VE, Ahmetshina OZ, Edomina NA, Zhukovskiy VA, Illarioniva EL. Kompozitsionnyie hirurgicheskie endoprotezyi s protivospaechnyimi svoystvami (Composite surgical endoprostheses with adhesion barrier) Dizayn. Materialyi. Tehnologiya. 2014;35(5):21-24. [In Russian]

3. Ellis H. Intraabdominal and postoperative peritoneal adhesions. J Am Coll Surg. 2005;200(5):641-4.

4. Minaev SV, Nemilova TK, Knorring GYu. Polifermentnaya terapiya v profilaktike spaechnogo protsessa $\mathrm{v}$ bryushnoy polosti u detey (Polyenzyme therapy for abdominal adhesion prevention in children). Vestn. hirurgii. 2006;165(1):49-54. [In Russian].

5. Beburishvili AG. Etapnyiy laparoskopicheskiy adgeziolizis s primeneniem protivospaechnyih barernyih sredstv (Second-look laparoscopy adhesiolysis with application of adhesion barriers). Endoskopicheskaya hirurgiya. 2010;1(20):20-4. [In Russian].

6. Senthilkumar MP, Dreyer JS, Senthilkumar MP. Peritoneal adhesions: pathogenesis, assessment and effects. Trop. Gastroenterol 2006;27(1):11-8.

7. Muller SA, Treutner KH, Anurov M. Experimental evaluation of phospholipids and icodextrin in reformation of peritoneal adhesions. Br J Surg. 2003;90(12):1604-7.

8. Bristow RE, Montz FJ. Prevention of adhesion formation after radical oophorectomy using a sodium hyaluronate-carboxymethylcellulose (HA-CMC) barrier. Gynecol Oncol. 2005;99(2):301-8.

9. Park SN, Jang HJ, Choi YS. Preparation and characterization of biodegradable anti-adhesive membrane for peritoneal wound healing. J Mater Sci Mater Med. 2007;18(3):475-82.

10. Lipatov VA. Kontseptsiya profilaktiki posleoperatsionnogo spechnogo protsessa bryushnoy polosti s primeneniem barernyih sredstv (eksperimentalno-klinicheskie issledovaniya) (The concept of preventing postoperative abdominal adhesions using adhesion barriers (experimental clinical studies). [thesis]. Kursk. 2013; 48 p. [In Russian]

11. Nemilov VE, Polyanskiy AV, Ahmetshina OZ, Zhukovskiy VA. Vodostoykie plenochnyie implantatyi na osnove karboksimetiltsellyulozyi (Water-resistant membranous implants with carboxymethylcellulose). Tez. mezhdunar. nauch.-prakt. konfer. "Meditsinskie implantatyi". 2016;81. [In Russian]

12. Beck DE. The role of Seprafilm bioresorbable membrane in adhesion prevention. Eur. Surg. Suppl. 1997;577:49-55.

13. Tarhan OR, Eroglu A, Cetin R. Effects of seprafilm on peritoneal fibrinolytic system. J Surg. 2005;75(8):690-2.

14. Zhukovskiy VA. Polimernyie implantatyi dlya rekonstruktivnoy hirurgii (Polymer implants for reconstructive surgery). "Innova". 2016;2(3):51-9. [In Russian]

15. Ito T, Yeo Y, Highley CB, Bellas E, Benitez CA, Kohane DS. The prevention of peritoneal adhesions by in situ cross-linking hydrogels of hyaluronic acid and cellulose derivatives Biomaterials. 2007;28(6):97583. doi: 10.1016/j.biomaterials.2006.10.021. 